\title{
Toward A Hypothesis Connecting Leadership And Entrepreneurship
}

\author{
John Zimmerman, Argosy University, USA
}

\begin{abstract}
This article makes a strong case for attempting to connect the measurement of leadership skills and entrepreneurial orientation using the Myers Briggs Type Indicator (MBTI) as a measurement instrument. There are other tools available such as the Entrepreneurial Quotient (EQ), the Entrepreneurial Attitude Orientation (EAO), and the Herrmann Brain Dominance Instrument (HBDI) (Huefner, Hunt, \& Robinson, 1996). While each of these instruments has promise and should be further evaluated, at this stage the MBTI appears to have the greatest utility for future planned research.
\end{abstract}

KEYWORDS: Leadership And Entrepreneurship; Myers Briggs Type Indicator

\section{INTRODUCTION}

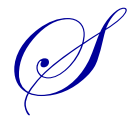

ignificant research has been conducted concerning the traits of successful leaders, and of successful entrepreneurs, but there is a gap in the research concerning entrepreneurship and leadership. This paper uses the case study method to analyze the activities of practitioner entrepreneurs to attempt to advance the understanding of the leadership dimension of the phenomenon of entrepreneurship.

Personality trait theory is considered as the lens with which to analyze leaders and as entrepreneurs. Personality trait theory attempts to use statistical analysis to reduce the bewildering variety of personality traits into a manageable number of basic dimensions. These traits are enduring characteristics of a person; ways of thinking or feeling that are relatively stable over time (Haslam, 2007). Traditional research has reduced these traits to five, sometimes known as the 'Big Five'. These are characterized as Extraversion, Agreeableness, Conscientiousness, Neuroticism/Emotional Stability, and Openness to Experience (John \& Srivastava, 1999). Atkinson et al. (2000) define these as:

- Openness to experience: (inventive/curious vs. consistent/cautious). [Defined as the] appreciation for art, emotion, adventure, unusual ideas, curiosity, and variety of experience. Openness reflects the degree of intellectual curiosity, creativity and a preference for novelty and variety a person has. It is also described as the extent to which a person is imaginative or independent, and depicts a personal preference for a variety of activities over a strict routine. Some disagreement remains about how to interpret the openness factor, which is sometimes called "intellect" rather than openness to experience.

- Conscientiousness: (efficient/organized vs. easy-going/careless). A tendency to be organized and dependable, show self-discipline, act dutifully, aim for achievement, and prefer planned rather than spontaneous behavior.

- Extraversion: (outgoing/energetic vs. solitary/reserved). [This trait is defined as having] energy, positive emotions, urgency, assertiveness, sociability and the tendency to seek stimulation in the company of others, and talkativeness.

- Agreeableness: (friendly/compassionate vs. analytical/detached). [This trait is defined as having] a tendency to be compassionate and cooperative rather than suspicious and antagonistic towards others. It is also a measure of one's trusting and helpful nature, and whether a person is generally well tempered or not. 
- $\quad$ Neuroticism/[Emotional Stability]: (sensitive/nervous vs. secure/confident). [This trait is defined as having] the tendency to experience unpleasant emotions easily, such as anger, anxiety, depression, and vulnerability. Neuroticism also refers to the degree of emotional stability and impulse control and is sometimes referred to by its low pole, "emotional stability".

Many readers may be more familiar with the terminology used by an instrument typically used commercially, the Myers-Briggs Type Indicator ${ }^{\circledR}\left(\right.$ MBTI $\left.^{\circledR}\right)$ (The Myers Briggs Foundation, n.d.), which was adapted from the work of C. G. Jung (Jung \& Baynes, 1921). The five dimensions used by this tool; Extraversion/Introversion, Sensing/Intuition, Thinking/Feeling, and Judging/Perceiving; roughly align with the 'Big Five' traits noted above. These five dimensions are used by the $\mathrm{MBTI}^{\circledR}$ instrument to develop 16 distinct personality types. This instrument is commonly used to evaluate personality traits for leadership training, and has proven popular in analyzing entrepreneurial activity.

While the $\mathrm{MBTI}^{\circledR}$ has proven to be a useful tool for studying leadership (see below), studies analyzing the application of personality trait theory to the study of entrepreneurs has been unable to provide definitive characterization of the entrepreneurial Gestalt (Carland, Carland, \& Stewart, 1996), and most researchers conclude that for the phenomenon of entrepreneurship "personality [traits] must be considered as one important component of a multidimensional model of the variable processes and environmental factors affecting entrepreneurship" (Zhao \& Siebert, 2006, p. 268).

For leadership, most research, e.g. Judge et. al. (Judge, Bono, Iles, \& Gerhardt, 2002) shows a strong correlation with the 'Big Five' factor model. Other studies support this claim and posit that there is evidence that certain traits are closely associated with successful leaders (Kirkpatrick \& Locke, 1991), and that leadership emerges from the combined influence of multiple traits as opposed to emerging from the independent assessment of traits. (Zaccaro, Kemp, \& Bader, 2004).

This paper attempts to develop a working hypothesis for future research in leadership in entrepreneurial settings using a four dimensional model of entrepreneurship developed in a previous paper (Zimmerman, 2008), and a review of the literature. Two of the dimensions from the model - procedural and behavioral - are proposed as significant in understanding entrepreneurial leaders, appearing to be more important in understanding the entrepreneur as leader. The procedural dimension of the model deals with the motivations that inspire individuals to undertake entrepreneurial ventures. The behavioral dimension attempts to analyze the values, actions, and conduct noted by the entrepreneurs as important for their success. By connecting existing research in leadership and entrepreneurship, a hypothesis and research methodology for studying the relationships of leadership traits and entrepreneurship are proposed.

\section{FIVE TRAITS OF ENTREPRENEURSHIP}

A number of scholars have studied the personality traits of entrepreneurship; propensity for risk-taking, need for achievement, need for autonomy, self-efficacy, and locus of control; that could possibly be associated with entrepreneurial orientation. Let's briefly discuss each of these.

Risk-taking while seemingly the most obvious, may be the most misunderstood personality trait for entrepreneurs. Risk-taking can be defined as a decision-making orientation toward accepting greater likelihood of loss in exchange for greater potential reward. Surprisingly, many researchers have been unable to establish clear connections between a propensity for risk-taking and entrepreneurial orientation (Brockhaus, 1976), with similar results noted by other scholars such as Litzinger (1965), and Masters and Meier (1988). Other scholars, however, were able to report a connection, especially between entrepreneurs and managers (Carland III, Carland, Carland, \& Pearce, 1995), and between entrepreneurs and the larger population (Stewart, Watson, Carland, \& Carland, 1998). These opposing research results can possibly be explained by studies conducted by Palich and Bagby (1995) and Cooper, Woo, and Dunkelberg (1988), who conclude that this can be explained not by the presence of any entrepreneurial personality trait but rather by an individual's assessment of a business scenario and/or confidence in their competence in decision-making. 
The connection between McClelland's need for achievement or achievement motivation (McClelland, 1961) and entrepreneurial traits has also been studied extensively. Several studies have reported that achievement motivation is associated with entrepreneurial orientation (Begley \& Boyd, 1987) and that entrepreneurs tend toward higher levels of achievement motivation than managers (Stewart et al., 1998). While others have not uniformly supported this contention (Brockhaus \& Horwitz, 1986), most research does support the connection between the need for achievement and entrepreneurial traits.

The desire to be independent and self-directing, or need for autonomy, is often considered to be related to entrepreneurial motivation. Intuitively this seems to make sense as working in large more bureaucratic organizations is assumed to result in suppression of personal freedom and less opportunity for personal expression, flexibility, or ability to control one's work situation or schedule. While there is some research supporting this contention (Harrell \& Alpert, 1979), the need for independence and autonomy has not been demonstrated empirically.

Bandura (1977) defines self-efficacy as one's belief in one's ability to succeed in specific situations. An individual's sense of self-efficacy can play a major role in how one approaches goals, tasks, and challenges. This trait has been shown to be connected to one's willingness to undertake new ventures as those who believe that they are capable of performing the tasks and activities associated with new venture creation will likely engage in entrepreneurial endeavors (Boyd \& Vozikis, 1994). This trait may help to explain why some individuals undertake or avoid entrepreneurial actions, and to initiate or shun certain critical new venture activities.

Closely related to the notion of self-efficacy (task specific) is the broader concept of locus of control. Locus of control, first postulated by Rotter (1966), refers to the extent to which individuals believe that they can control events that affect them. However, studies attempting to connect locus of control with entrepreneurial orientation have not established a relationship (Gatewood, Shaver, \& Gartner, 1995). While this entrepreneurial trait may seem to be associated with entrepreneurial orientation, empirical evidence has not as yet been established.

\section{The Four Dimension Model of Entrepreneurship}

In previous research a four dimension model for entrepreneurship (Zimmerman, 2008) was proposed:

Table 1: Four Dimension Model of Entrepreneurship

\begin{tabular}{|c|c|c|c|c|}
\hline Dimension & Procedural & Typological & Behavioral & Environmental \\
\hline $\begin{array}{l}\text { Elements of } \\
\text { Each Dimension - } \\
\text { Insights of Thirteen } \\
\text { Practitioner } \\
\text { Entrepreneurs }\end{array}$ & $\begin{array}{l}\text { Opportunity } \\
\text { Recognition or } \\
\text { Creation } \\
\text { Innovation or } \\
\text { Invention } \\
\text { Genesis Moment } \\
\text { Action }\end{array}$ & $\begin{array}{l}\text { Social } \\
\text { Lifestyle } \\
\text { Intrapreneur } \\
\text { Middle Market } \\
\text { Liquidity Event }\end{array}$ & $\begin{array}{l}\text { Personal Values } \\
\text { Self-Awareness } \\
\text { Self-Discipline } \\
\text { Intellectual } \\
\text { Curiosity } \\
\text { Intellectual Honesty } \\
\text { Accountability }\end{array}$ & $\begin{array}{l}\text { Legal System } \\
\text { Education System } \\
\text { Research University } \\
\text { Vibrant Economy }\end{array}$ \\
\hline Unit of Analysis & $\begin{array}{c}\text { The Process or the } \\
\text { Act }\end{array}$ & The Venture & The Entrepreneur & The Ecosystem \\
\hline
\end{tabular}

The Procedural and Behavioral Dimensions of this model appear to align with leadership trait theory. Therefore this connection will be explored in this paper, but first further meaning concerning the two dimensions identified will be provided.

The Procedural Dimension deals with the act and process of entrepreneurship. The very nature and definition of the phenomenon of entrepreneurship requires two basic ingredients, "enterprising individuals" and 
"entrepreneurial opportunities", and researchers often attempt to study the nature of the individuals who respond to these opportunities when others do not, the opportunities themselves and the nexus between individuals and opportunities (Shane \& Venkataraman, 2000). Specifically, the research shows that the process of entrepreneurship involves the existence, or creation of an opportunity. This opportunity involves innovation (the improved and novel use of an existing idea or method) or invention (a unique or novel device, method, composition or process) by the entrepreneur, a so-called "genesis moment" when the entrepreneur chooses to undertake risk by enacting their idea (Zimmerman, 2008). Hence the unit of analysis for the Procedural Dimension is the process of entrepreneurship itself. The potential implications for leadership in entrepreneurial settings for this dimension include addressing the questions of: "why is it that some individuals chose to undertake entrepreneurship while others do not", and "what leadership traits are involved in organizing and implementing the entrepreneurial endeavor?" These questions deal with the leadership traits or behaviors of the entrepreneur during the early stages of the process.

The Behavioral Dimension of the model involves the actions that entrepreneurs engage in to carry out the phenomenon of entrepreneurship. Therefore the unit of analysis for this dimension is the entrepreneurs themselves as they engage in launching and leading their ventures. Research shows that certain entrepreneurial behaviors are what is significant, and not any innate traits that the entrepreneurs may possess and that the behaviors reported as most significant were a personal system of values, self-awareness, self-discipline, intellectual honesty and curiosity, and accountability (Zimmerman, 2008). The possible implications for leadership in entrepreneurial settings entail the questions of: "just how important is leadership in entrepreneurial settings, can we predict the likelihood of entrepreneurial success by examining the innate traits and practiced behaviors of entrepreneurs, how do these behaviors align with traditional leadership trait theory, and if leadership is important, can leadership be learned?"

\section{PERSONALITY TRAITS AND LEADERSHIP}

Innovation/invention, opportunity recognition, propensity to accept risk, and a bias toward action are all important, even necessary, for entrepreneurship. The Four Dimension Model described above, as well as research by many others (Carland, Carland, \& Stewart, 1996; Gardner \& Martinko, 1996; Shane \& Venkataraman, 2000; et al.), all emphasize the significance of these factors. But how do these personality traits align with leadership trait theory? Judge (2002), in particular, notes that four of the "Big Five" personality traits correlate closely with leadership, three positively, one negatively, with one showing little correlation. Extraversion, the tendency to be sociable, assertive, active, and to experience positive effects, such as energy and zeal, shows a high positive correlation with leadership. Also, Openness, the disposition to be imaginative, nonconforming, unconventional, and autonomous, and Conscientiousness, seeking achievement and displaying dependability, were also highly positively correlated. On the other hand, Neuroticism, the tendency to exhibit poor emotional adjustment and experience negative effects, such as anxiety, insecurity, and hostility, showed a high negative correlation. The fifth trait, Agreeableness, the tendency to be trusting, compliant, caring, and gentle, was not significantly correlated.

Therefore, research shows that certain personality traits can be correlated closely with leadership trait theory. But is it possible to extend these relationships to entrepreneurship? To attempt this, the Elements from the Procedural and Behavioral Dimensions of entrepreneurship must be connected to the personality traits noted above.

\section{A WORKING HYPOTHESIS CONNECTING PERSONALITY TRAITS AND ENTREPRENEURSHIP}

The goal of this paper is to review the literature connecting personality, entrepreneurial, and leadership traits in order to attempt to establish connections to establishment measurement instruments. By forming this relationship future research will be able to make progress in addressing key unanswered questions about the phenomenon of entrepreneurship. One instrument that appears to have potential is the Myers-Briggs Personality Type Indicator.

Research has shown that the Myers-Briggs Type Indicator closely aligns with the Big Five personal traits and that the MBTI instrument can be used as a measurement tool (Harvey, Murry, \& Markham, 1995). This paper argues that the elements reported by the participants that were used to develop the Four Dimension Model could be aligned with the "Big Five" personality traits that most closely correlate with leadership. There appears to be a strong connection between the Big Five Personality Traits, the Four Dimension Model, and the MBTI. 
Openness appears to be aligned with the elements of Innovation, Opportunity Creation/Recognition, and Intellectual Curiosity, which in turn connects with the MBTI preferences of Sensing and Feeling. Conscientiousness associates with Self-Discipline, Accountability, and Intellectual Curiosity, which relates to Judging and Perceiving. Extraversion supports the Genesis Moment and Decision to Act which ties to Extraversion and Introversion. Agreeableness links with Personal Values and Self-Awareness, which in turn supports the preferences of Thinking and Feeling. Lastly, no connection is established for Neuroticism/Emotional Stability. Table 2 below summarizes these proposed relationships:

Table 2. Summary of Big Five Traits, Four Dimension Model, and MBTI

\begin{tabular}{|c|c|c|c|c|}
\hline Big Five Traits & Characteristics & $\begin{array}{l}\text { Illustrative Adjectives } \\
\text { (Antonym) }\end{array}$ & $\begin{array}{c}\text { Entrepreneurship } \\
\text { Trait } \\
\text { Four Dimension } \\
\text { Model } \\
\end{array}$ & $\begin{array}{l}\text { Myers-Briggs Type } \\
\text { Indicator }\end{array}$ \\
\hline Openness & $\begin{array}{l}\text { Imaginative, artistically } \\
\text { sensitive, aesthetically } \\
\text { sensitive, intellectual, } \\
\text { depth of feeling, } \\
\text { curiosity, need for } \\
\text { variety }\end{array}$ & $\begin{array}{c}\text { Intellectual, creative, } \\
\text { artistic, imaginative, } \\
\text { curious, original, } \\
\text { (unimaginative), } \\
\text { (conventional), } \\
\text { (simple), } \\
\text { (dull), (literal-minded) }\end{array}$ & $\begin{array}{c}\text { Opportunity } \\
\text { Recognition/Creation } \\
\text { Innovation/Invention } \\
\text { Intellectual Curiosity }\end{array}$ & $\begin{array}{l}\text { Sensing/Intuition } \\
(\mathrm{S}-\mathrm{N})\end{array}$ \\
\hline $\begin{array}{c}\text { Conscientious- } \\
\text { ness }\end{array}$ & $\begin{array}{c}\text { Responsible, } \\
\text { dependable, } \\
\text { able to plan, organized, } \\
\text { persistent, need for } \\
\text { achievement, } \\
\text { persistence, } \\
\text { scrupulousness }\end{array}$ & $\begin{array}{l}\text { Organized, systematic, } \\
\text { thorough, hardworking, } \\
\text { planful, neat, } \\
\text { dependable, } \\
\text { (careless), (inefficient), } \\
\text { (sloppy), (impulsive), } \\
\text { (irresponsible) }\end{array}$ & $\begin{array}{c}\text { Self-Discipline } \\
\text { Accountability } \\
\text { Intellectual Honesty }\end{array}$ & $\begin{array}{c}\text { Judging/Perceiving ( } \mathrm{J}- \\
\mathrm{P})\end{array}$ \\
\hline Extraversion & $\begin{array}{l}\text { Sociable, talkative, } \\
\text { assertive, ambitious, } \\
\text { active, dominance, } \\
\text { tendency to experience } \\
\text { positive emotions }\end{array}$ & $\begin{array}{l}\text { Extroverted, talkative, } \\
\text { assertive, gregarious, } \\
\text { energetic, self- } \\
\text { dramatizing, } \\
\text { (reserved), } \\
\text { (introverted), } \\
\text { (quiet), (shy), } \\
\text { (unassertive), } \\
\text { (withdrawn) } \\
\end{array}$ & $\begin{array}{l}\text { Genesis Moment } \\
\text { Decision to Act }\end{array}$ & $\begin{array}{c}\text { Extravision } \\
\text { /Intravision (E-I) }\end{array}$ \\
\hline Agreeableness & $\begin{array}{c}\text { Good-natured, } \\
\text { cooperative, trusting, } \\
\text { sympathy, altruism, } \\
\text { (hostility), } \\
\text { (unsociability) }\end{array}$ & $\begin{array}{c}\text { Sympathetic, } \\
\text { cooperative, } \\
\text { warm, tactful, } \\
\text { considerate, } \\
\text { trustful, (cold), (rude), } \\
\text { (unkind), (independent) }\end{array}$ & $\begin{array}{l}\text { Personal Values } \\
\text { Self-Awareness }\end{array}$ & $\begin{array}{c}\text { Thinking/Feeling } \\
\text { (T-F) }\end{array}$ \\
\hline $\begin{array}{c}\text { Neuroticism } \\
\text { Emotional } \\
\text { Stability }\end{array}$ & $\begin{array}{c}\text { Calm, secure, not } \\
\text { nervous; } \\
\text { (predisposition to } \\
\text { experience anxiety, } \\
\text { anger, depression, } \\
\text { emotional instability) }\end{array}$ & $\begin{array}{c}\text { Calm, secure, not } \\
\text { nervous; } \\
\text { (predisposition to } \\
\text { experience anxiety, } \\
\text { anger, } \\
\text { depression, emotional } \\
\text { instability) }\end{array}$ & None exhibited & None exhibited \\
\hline
\end{tabular}

Note. Adapted from Harvey et al. (1995). Prototypical characteristics and adjectives taken from McCrae and Costa (1989), Mount et al. (1994), and Hogan (1991); items in parentheses define the opposite pole of each dimension.

It should be noted that MBTI attempts to measure an individual's preferences, not their ability or aptitude for certain attitudes (Extraversion/Introversion or E-I), methods of gathering information (Sensing/Intuition or S-N), methods of deciding (Thinking/Feeling or T-F), or relating to the outside world (Judging/Perceiving or J-P). MBTI maintains that the four pair scales of preferences or dichotomies can be measured to develop 16 personality types. While MBTI certainly has its share of detractors, with the exception of the neuroticism trait, most research has 
established a correlation between certain of the MBTI personality types and the Big Five. McCrae and Costa (1989) have contributed significantly in this area and the results from one study are summarized below:

Table 3. Correlation between MBTI and Big Five

\begin{tabular}{|l|l|l|l|l|}
\hline & Extraversion & Openness & Agreeableness & Conscientiousness \\
\hline E-I & $\mathbf{- 0 . 7 4}$ & 0.03 & -0.03 & 0.08 \\
\hline S-N & 0.10 & $\mathbf{0 . 7 2}$ & 0.04 & -0.15 \\
\hline T-F & 0.19 & 0.02 & $\mathbf{0 . 4 4}$ & $-0,15$ \\
\hline J-P & 0.15 & 0.30 & -0.06 & $\mathbf{- 0 . 4 9}$ \\
\hline
\end{tabular}

There are natural relationships between the Elements of the Procedural and Behavioral Dimensions of the Four Dimension Model and both the Big Five personality traits and the MBTI. The argument for these connections is found by examining the characteristics and illustrations provided in Table 2. The characteristics for the Openness trait (imaginative, creative for example) align with the elements relating to opportunity, risk taking, etc. The characteristics for Conscientiousness naturally support the elements of self-discipline, intellectual honesty, and accountability. Extraversion connects well with decisiveness and action orientation. Agreeableness seems to support the elements of having a personal values system, and self-awareness.

The working hypothesis proposed is that the MBTI can be used as an instrument to assess an individual's preferred personality traits and that this can be extended to assess their leadership aptitude and entrepreneurial orientation. This information could then be used to answer the important research questions posed previously in this paper, such as: "why is it that some individuals chose to undertake entrepreneurship while others do not, what leadership traits are involved in organizing and implementing the entrepreneurial endeavor, how important is leadership in entrepreneurial settings, can we predict the likelihood of entrepreneurial success by examining the innate traits and practiced behaviors of entrepreneurs, how do these behaviors align with traditional leadership trait theory, and if leadership is important, can leadership and entrepreneurship be learned?"

\section{CONCLUSIONS AND FUTURE RESEARCH}

In summary, a strong case has been presented for attempting to connect the measurement of leadership skills and entrepreneurial orientation using the Myers Briggs Type Indicator as a measurement instrument. While this approach appears to have promise, there are other tools available such as the Entrepreneurial Quotient (EQ), the Entrepreneurial Attitude Orientation (EAO), and the Herrmann Brain Dominance Instrument (HBDI) (Huefner, Hunt, \& Robinson, 1996). While each of these instruments has promise and will be further evaluated, at this stage the MBTI appears to have the greatest utility for future planned research. This future research will attempt to validate this working hypothesis and develop empirical support.

\section{AUTHOR INFORMATION}

John "Jack" Zimmerman, Ph.D., Argosy University, School of Business, Argosy University, 5001 Lyndon B. Johnson Freeway, Heritage Square, Farmers Branch, 75244 Dallas, Texas, 75244 USA. Email: zimmermanjohn1@gmail.com

\section{REFERENCES}

1. Atkinson, R. L., Smith, E. E., Bem, D. J., \& Nolan-Hoeksema, S. (2000). Hilgard's Introduction to Psychology (13 ed.). Orlando, Florida: Harcourt Publishers.

2. Bandura, A. (1977). Self-efficacy: Toward a Unifying Theory of Behavioral Change. Psychological Review, 84, 191-215.

3. Begley, T., \& Boyd, D. (1987). Psychological characteristics associated with performance in entrepreneurial firms and small business. Journal of Business Venturing, 2, 79-93.

4. Boyd, N. G., \& Vozikis, G. S. (1994). The influence of self-efficacy in the development of entrepreneurial intentions and actions. Entrepreneurship Theory and Practice, 18, 63-90. 
5. $\quad$ Brockhaus, R. H. (1976). Risk-taking propensity of entrepreneurs. Proceedings of the Academy of Management, 457-460.

6. Brockhaus, R. H., \& Horwitz, P. S. (1986). The art and science of entrepreneurship. (D. Sexton \& R. Smilor, Eds.). Cambridge, MA: Ballinger.

7. Carland III, J. W., Carland, J. W., Carland, J. A., \& Pearce, J. W. (1995). Risk-taking propensity among entrepreneurs, small business owners, and managers. Journal of Business and Entrepreneurship, 7, 15-23.

8. Carland, J. C., Carland, J. W., \& Stewart, W. H. (1996). Seeing what's not there: The enigma of entrepreneurship. Journal of Small Business Strategy, 7(1), 1-20.

9. Cooper, A. C., Woo, C. Y., \& Dunkelberg, W. C. (1988). Entrepreneurs' perceived chances for success. Journal of Business Venturing, 3, 97-108.

10. Dunnette, M., \& Hough, L. (Eds.). (1991). Handbook of industrial and organizational psychology (2ed.). Palo Alto: Consulting Psychologists Press.

11. Gardner, W. L., \& Martinko, M. J. (1996). Using the Myers Briggs Type Indicator to study managers: A literature review and research agenda. Journal of Management, 22, .

12. Gatewood, E. J., Shaver, K. G., \& Gartner, W. B. (1995). A longitudinal study of cognitive factors influencing start-up behaviors and success at venture creation. Journal of Business Venturing, 10, 371-391.

13. Harrell, T., \& Alpert, B. (1979). The need for autonomy among managers. Academy of Management Review, 4, 259-267.

14. Harvey, R. J., Murry, W. D., \& Markham, S. E. (1995). A "Big Five" scoring system for the Myers-Briggs Type Indicator. Annual Conference of the Society for Industrial and Organizational Psychology, 1-9.

15. Haslam, N. (2007). Trait psychology. Foundations of Psychology: Introduction to personality and intelligence, London: Sage Publications, 17-46.

16. Hogan, R. (1991). Handbook of industrial and organizational psychology (2ed ed.). (M. Dunnette \& L. Hough, Eds.). Palo Alto: Consulting Psychologists Press..

17. Huefner, J. C., Hunt, K. H., \& Robinson, P. B. (1996). A comparison of four scales predicting entrepreneurship. Academy of Entrepreneurship Journal, 1, 1-17.

18. John, O. P., \& Srivastava, S. (1999). The Big Five trait taxonomy: History, measurement, and theoretical perspectives. In L. A. Pervin (Ed.), Handbook of personality: Theory and research (2nd ed.) (pp. 102-138). New York: Guilford.

19. Judge, T. A., Bono, J. E., Iles, R., \& Gerhardt, M. W. (2002). Personality and leadership: A qualitative and quantitative review. Journal of Applied Psychology, 87, 765-780.

20. Jung, C. G., \& Baynes, H. G. (1921). The Psychology of Individuation. London: Kegan Paul Trench Trubner.

21. Kirkpatrick, S. A., \& Locke, E. A. (1991). Leadership: Do traits matter? The Executive, 5, 48-60.

22. Litzinger, W. (1965). The motel entrepreneur and the motel manager. Academy of Management Journal, 8, 268-281.

23. Masters, R., \& Meier, R. (1988). Sex differences and risk-taking propensity of entrepreneurs. Journal of Small Business Management, 26, 31-35.

24. McClelland, D. C. (1961). The Achieving Society. New York: Free Press.

25. McCrae, R. R., \& Costa, P. T. (1989). Reinterpreting the Myers-Briggs Type Indicator from the perspective of the five factor model of personality. Journal of Personality, 57, 17-40.

26. Mount, M. K., Barrick, M. R., \& Straus, J. P. (1994). Validity of observer ratings of the Big Five personality factors. Journal of Applied Psychology, 79, 272-280.

27. Palich, L. E., \& Bagby, D. R. (1995). Using cognitive theory to explain entrepreneurial risk-taking: challenging conventional wisdom. Journal of Business Venturing, 10, 425-438.

28. Rotter, J. B. (1966). Generalized expectancies for internal versus external control of reinforcement. Psychological Monographs: General \& Applied, 80, 1-28.

29. Shane, S., \& Venkataraman, S. (2000). The promise of entrepreneurship as a field of research. The Academy of Management Review, 25(1), 217-226.

30. Stewart, W. H., Watson, W. E., Carland, J. C., \& Carland, J. W. (1998). A proclivity for entrepreneurship: a comparison of entrepreneurs, small business owners, and corporate managers. Journal of Business Venturing, 14, 189-214.

31. The Myers Briggs Foundation (n.d.). MBTI Basics. Retrieved January 7, 2014, from http://www.myersbriggs.org/my-mbti-personality-type/mbti-basics/ 
32. Vecchio, R. P. (2003). Entrepreneurship and leadership: common trends and common threads. Human Resource Management Review, 13, 303-327.

33. Zaccaro, S. J., Kemp, C., \& Bader, P. (2004). Leader traits and attributes. The nature of leadership (ed.). Thousand Oaks, CA: Sage Publications.

34. Zhao, H., \& Siebert, S. E. (2006). The Big Five personality dimensions and entrepreneurial status: A metaanalytical review. Journal of Applied Psychology, 91, 259-271.

35. Zimmerman, J. (2008). Refining the Definition of Entrepreneurship. Dissertations Abstracts International, (UMI No. 3291609) 